\title{
CORRESPONDENCE
}

\section{Late Precambrian and Early Palaeozoic Tillites of the Taoudeni Basins, West Africa}

SIR - In a recent world wide compilation of tillites - Earth's Pre-Pleistocene Glacial Record (1981, ed. M. J. Hambrey and W. B. Harland, Cambridge University Press) - two papers were published concerning the Late Precambrian and Late Ordovician glacigenic deposits of the Taoudeni Basin in Mauritania, Mali and Algeria (Deynoux and Trompette, papers A19 and A13, 1981 $a, b$ ). The distributions of these glacial horizons are broadly similar, and inadvertently the same Late Precambrian map was used to illustrate both papers. We wish to take this opportunity to correct this mistake and offer our apologies to Dr Deynoux and Professor Trompette.

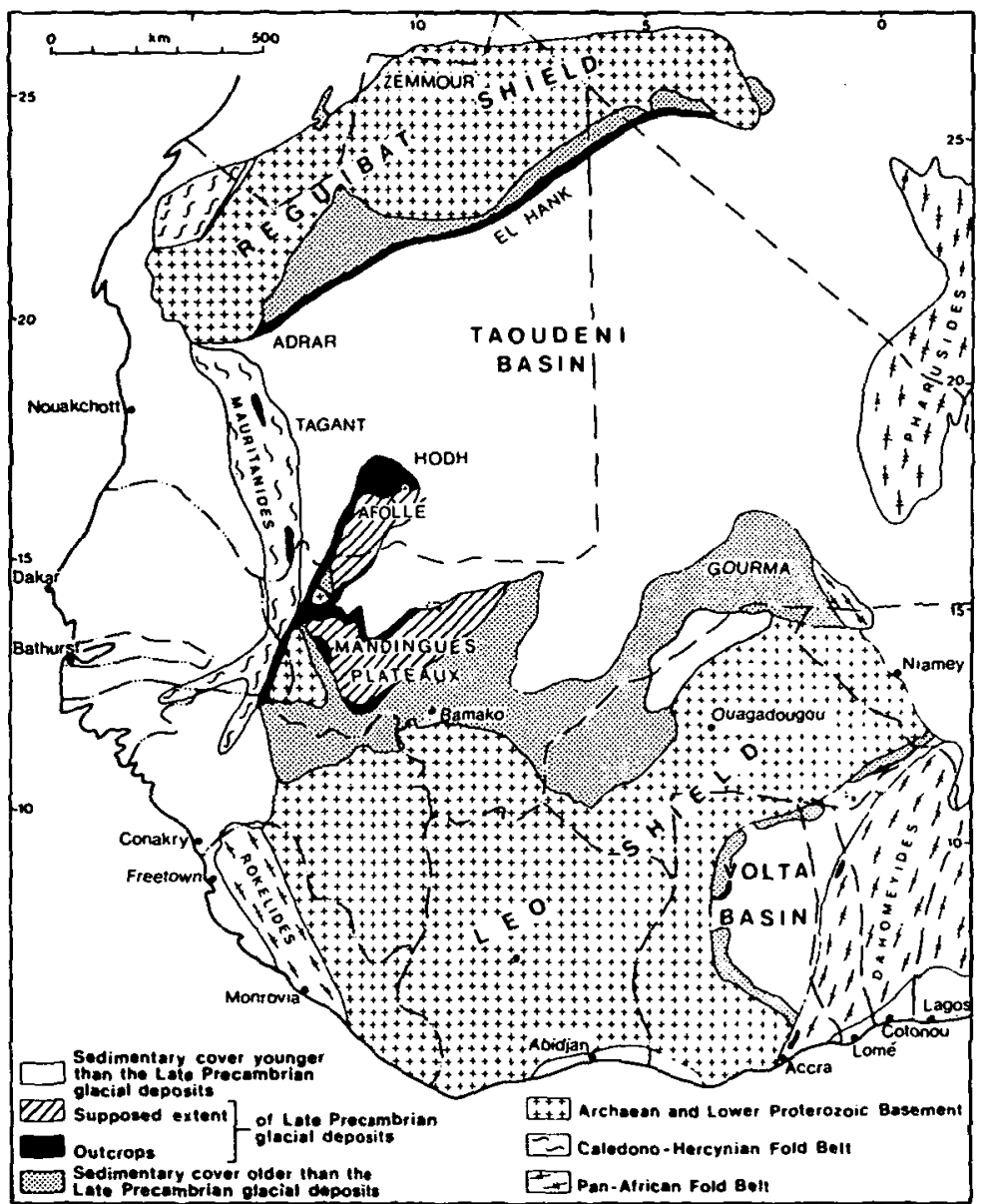

Figure 1. Schematic geological map of West Africa showing the distribution of the Upper Ordovician glacial deposits.

Figures 1 and 2 illustrate the approximate distributions of Late Precambrian and Late Ordovician tillite-bearing strata. They are largely terrestrial, and glacial erosional features are beautifully preserved. Deynoux (1978) made an exhaustive study of these deposits. The Taoudeni Basin is represented by a 2000-3000 m thick sedimentary cover on the West African craton, the strata ranging in age from about $1000 \mathrm{Ma}$ to Carboniferous. The stratigraphic position of the tillites (denoted by triangles) is summarized as follows (Deynoux, 1978):

Geol. Mag. 120 (4), 1983, pp. 390-392. Printed in Great Britain. 


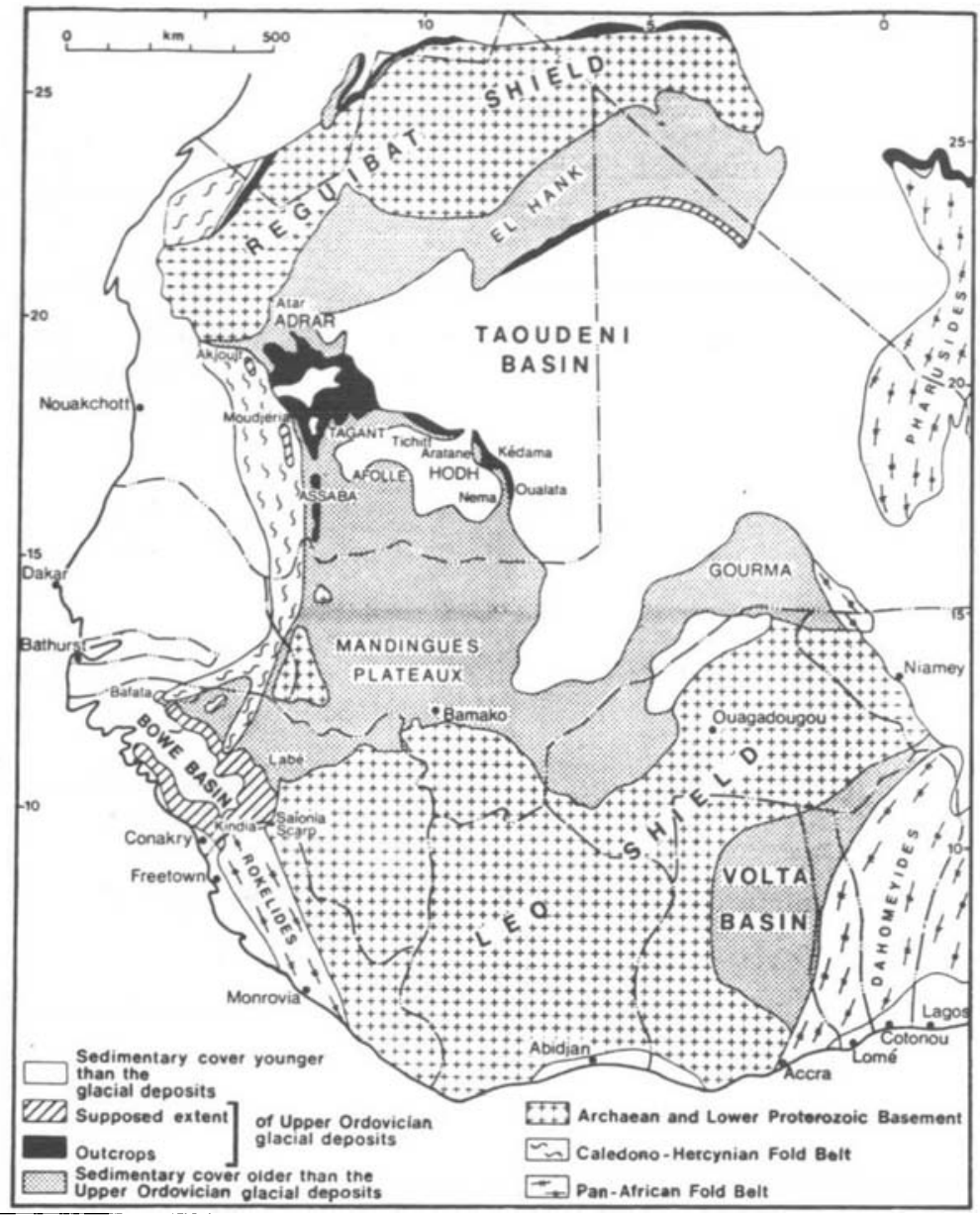

Figure 2. Schematic geological map of West Africa showing the distribution of the Late Ordovician glacial deposits.

Supergroup 3 (c. $500 \mathrm{~m})$

Oued Chig Group (Silurian)

- Njakana-Abteilli Group (Upper Ordovician)

- Unconformity -

Supergroup 2 (c. $1200 \mathrm{~m}$ )

Oujeft Plateau Group

Atar Cliff Group (Cambrian)

Teniagouri Group (595 $\pm 43 \mathrm{Ma}$ )

- Jbéliat Group

- Unconfirmity -

Supergroup 3 (c. $1300 \mathrm{~m}$ )

Assabet et Hassian Group ( $\geqslant 694 \mathrm{Ma}$ )

- Unconformity -

Tifounke Group

- Unconformity - 
Atar Group (several radiometric dates ranging from $775 \pm 52$ to $890 \pm 35)$

- Unconformity -

Char Group (998 $\pm 32 \mathrm{Ma})$

- Unconformity -

Basement (c. $2800 \mathrm{Ma}$ )

The Late Proterozoic tillites in the Taoudeni Basin are broadly coeval with the later of the two Varangian epochs in the North Atlantic region (Hambrey, 1983). The Late Ordovician tillites belong to a short-lived but extensive phase of continental glaciation, which affected much of Gondwanaland and adjacent areas.

\title{
References
}

Deynoux, M. 1978. Les formations glaciaires du Précambrien Terminal et de la fin de l'Ordovicien en Afrique de l'ouest. Trav. Lab. Sci. Terre St Jérôme, Marseille.

Deynoux, M. \& Trompette, R. 1981 (a). Late Precambrian tillites of the Taoudeni Basin, West Africa. Paper A19 in Earth's Pre-Pleistocene Glacial Record (ed. M. J. Hambrey and W. B. Harland). Cambridge: Cambridge University Press.

Deynoux, M. \& Trompette, R. $1981(b)$. Late Ordovician tillites of the Taoudeni Basin, West Africa. Paper A13 in Earth's Pre-Pleistocene Glacial Record (ed. M. J. Hambrey and W. B. Harland). Cambridge: Cambridge University Press.

Hambrey, M. J. 1983. Correlation of Late Proterozoic tillites in the North Atlantic region and Europe. Geol. Mag. 120, 209-32.

\author{
M. J. HAMBREY \\ W. B. HARLAND \\ Department of Earth Sciences \\ Downing Street \\ Cambridge CB2 3EQ \\ 25th February 1983
}

